\title{
Ethnobotany and Effects of Harvesting on the Population Ecology of Syngonanthus nitens (Bong.) Ruhland (Eriocaulaceae), a NTFP from Jalapão Region, Central Brazil $^{1}$
}

\author{
Isabel Belloni Schmidt ${ }^{*}, 2,3,4$, Isabel Benedetti Figueiredo ${ }^{3,4}$, and \\ Aldicir SCARIOT ${ }^{5,6}$
}

${ }^{2}$ Brazilian Environmental Agency (Ibama, DIREF), SCEN Trecho 2, CEP 70818-900, Brasília, DF, Brazil

${ }^{3}$ Ecology Graduate Program, University of Brasília, P.O. Box 04457, CEP 70910-900, Brasilia, DF, Brazil

${ }^{4}$ PEQUI-Pesquisa e Conservação do Cerrado, SCLN 113, Bloco B, sala 109, CEP 70763-520, Brasília, DF, Brazil

${ }^{5}$ UNDP, SCN Quadra 2, Bloco A, Ed. Corporate Financial Center, CEP 70712-901, Brasília, DF, Brazil

${ }^{6}$ Laboratório de Ecologia e Conservação, Embrapa Recursos Genéticos e Biotecnologia (Cenargen), Parque Estação Biológica, final W5 Norte, Caixa Postal 02372, CEP 70770-900, Brasília, DF, Brazil "Corresponding author; e-mail: isabelbs@yahoo.com

\begin{abstract}
Ethnobotany and Effects of Harvesting on the Population Ecology of Syngonanthus Nitens (Bong.) Ruhland (Eriocaulaceae), a NTFP from Jalapão Region, Central Brazil. The handicrafts made from Syngonanthus nitens scapes have been an important source of income for rural communities in the Jalapão regıon of Brazil since the late 1990s. Thıs study analyzed S. nitens harvest and management techniques and the economic importance of the handicrafts. We also tested the effects of harvest on $S$. nitens population ecology. Handicrafts provide about US $\$ 1,800 /$ year per artisan, being especially important to women. Experimental scape harvesting in mid-October, which is when knowledgeable artisans harvest and when the seeds are mature, had no consistent effects on population density, plant survival, or reproduction (clonal or sexual) after one year. Since $40 \%$ of the new recruits come from seeds, harvest after seed maturation, combined with removal of only the scapes and not the flowerheads, can allow for $S$. nitens seeds to remain in the populations and help ensure sustainability of the growing $S$ nitens handicraft activity. Important economic aspects of $S$. nitens harvest sustannability include the high value of the handicrafts and the fact they are not perishable.
\end{abstract}

Etnobotânica e efeitos do extrativismo na ecologia populacional de Syngonanthus nitens (Bong.) Ruhland (Eriocaulaceae), um produto florestal não-madeireiro (PFNM) da região do Jalapão, Tocantins, Brasil. O artesanato de escapos de Syngonanthus nitens (capim dourado) é importante fonte de renda para comunidades do Jalapão, Tocantins, desde o fim dos anos 1990. Este estudo caracterizou a importância econômica deste artesanato, as técnicas de manejo e extrativismo e testou efeitos da colheita sobre a ecologia populacional da espécie. O artesanato rende cerca de US $\$ 1.800 /$ artesão anualmente ( R $\$ 345,00 / \mathrm{mês})$, sendo especialmente importante para mulheres. A colheita experimental de escapos em meados de outubro, época de colheita declarada por artesãos tradicionais, e quando as sementes estão maduras, não afetou de maneira consistente a densidade populacional, a sobrevivência ou a reprodução (sexuada e assexuada) das plantas por um ano. Um aspecto Importante deste artesanato é o interesse estar voltado para o escapo, e não para os capítu-

${ }^{1}$ Received 17 June 2006; accepted 8 December 2006. 


\begin{abstract}
los, como ocorre para utllização de outras sempre-vivas para ornamentação de interiores Assim, a recomendação de colher após a maturação das sementes e cortar os capítulos não prejudica a atıvidade artesanal e mantém as sementes nos campos úmidos, o que é ımportante para a dinâmica populacional, visto que $40 \%$ dos recrutas provem de sementes. Aspectos importantes para a sustentabilidade conômica da atividade são o alto valor de mercado e o fato do artesanato não ser um produto perecível.
\end{abstract}

Key Words: Syngonanthus nitens, Brazılian Cerrado, handıcraft, scape harvestıng, herb, resource management, economic importance, biodiversity.

The harvest of non-timber forest products (NTFP) has been identified as a possible way to combine biodiversity conservation with income generation in rural communities around the world (Nepstad and Schwartzman 1992; Redford and Padoch 1992; Ticktin 2004). However, some authors argue that it may be difficult for NTFP to guarantee economic and/or ecological sustainability. This is either because the values of NTFP are overestimated and do not represent a reliable income source, or because the shift from subsistence harvesting to a commercial scale leads to overexploitation of natural resources (Belcher et al. 2005; Boot and Gullison 1995; Hall and Bawa 1993; Redford and Padoch 1992).

The harvesting of NTFP can have different impacts on the individuals and plant populations exploited depending on the plant life history, the part of the plant harvested, and the intensity and time of harvesting, as well as environmental and management conditions (Ticktin 2004). To determine the economic significance and ecological impacts of the harvesting and sale of NTFP, it is essential to understand the harvesting and management techniques applied by local harvesters and to test experimentally the effects of harvesting on individuals and populations (Endress et al. 2004; Hall and Bawa 1993; Martin 2004; Paoli et al. 2001; Ticktin and Johns 2002).

In Central Brazil, various species from the Eriocaulaceae, Xyridaceae, and Cyperaceae families are heavily harvested for their scapes (flower stalks or stems) and flowerheads, which are used as dry ornamental plants (sempre-vivas). This trade has occurred since the end of $19^{\text {th }}$ century and holds high economic importance, especially in the states of Minas Gerais, Bahia, and Goiás (Giulietti et al. 1988). This commercial exploitation is thought to be responsible for the population declines of several species which are now considered at risk of extinction on a regional scale (Giulietti et al. 1996; Mendonça and Lins 2000).
However, no published studies to date have examined the effects of scape harvesting on the population ecology and dynamics of these species.

In the Jalapão region, Tocantins state, handicrafts made from the scapes of Syngonanthus nitens (Bong.) Ruhland (Eriocaulaceae) (Fig. 1) have been a very important source of income to local communities since the late 1990s. Over the last few years, the demand for $S$. nitens handicrafts has put increased pressure on plant populations as the number of artisans and the demand for raw material has increased. Due to concerns about the increasing number of new artisans, families from a local community (Mumbuca) asked the Brazilian federal environmental agency (Ibama) to propose management techniques to prevent overexploitation of $S$. nitens. The present study was carried out as part of an effort to guarantee ecological and economic sustainability to the handicraft activity in the region. The Jalapão region is in the Cerrado biome, which originally covered more than 2 million $\mathrm{km}^{2}$, mainly in Central Brazil. Despite its high biological diversity and rates of endemism as well as its importance to local communities' livelihoods, the Cerrado has been overlooked by many conservation initiatives (Silva and Bates 2002; Marris 2005). Promoting sustainable uses of Cerrado products is one strategy to promote the conservation of this biodiversity hotspot (Klink and Machado 2005).

In this study, we aimed to (1) characterize the harvesting, management, and crafting techniques and the economical importance of Syngonanthus nitens handicrafts in Jalapão region; (2) quantify $S$. nitens density, survival, flowering, and reproductive rates over a one year period; and (3) test the effects of scape harvesting on $S$. nitens individuals and populations by comparing the plant density and rates of survival, flowering, and resprouting in harvested and unharvested (control) plots. 


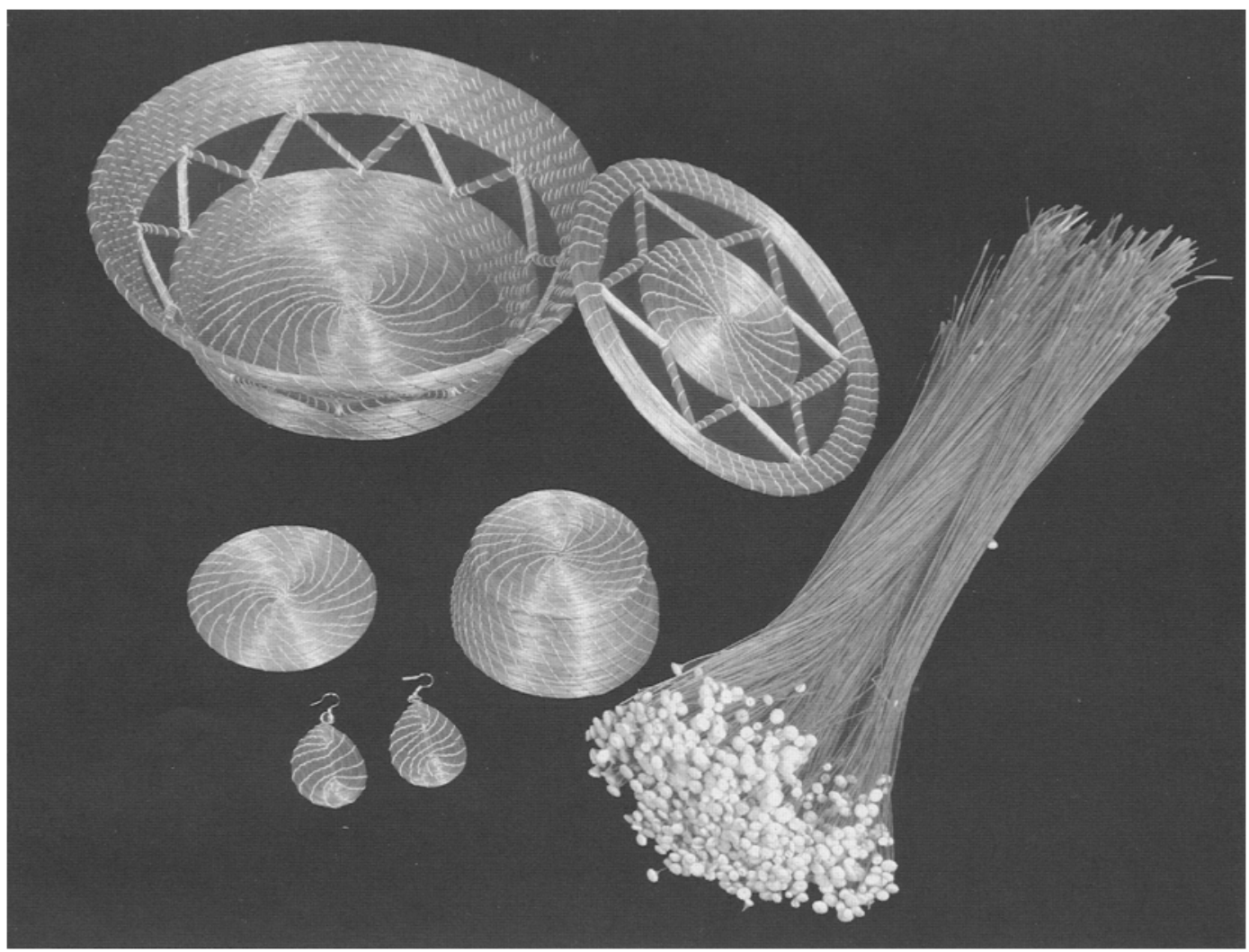

Fig. 1. Handicraft pieces made from Syngonanthus nitens scapes.

\section{Methods}

\section{Study Area}

Our study sites are located in the Jalapão region within the Cerrado biome. The savanna-like vegetation of this biome has been largely converted to extensive monocultures, especially soybean and pastures (Furley 2004; Myers et al. 2000; Oliveira and Marquis 2002). Today more than $80 \%$ of the Cerrado area has been disturbed (Mittermeier et al. 2000), and only 2.6\% of the biome is inside protected areas (Aguiar et al. 2004). The Jalapão is a $53,340 \mathrm{~km}^{2}$ region in Tocantins State. Its isolation, combined with its sandy, nutrient-poor soils, has made it unattractive to large-scale agricultural uses, thus contributing to the preservation of the natural vegetation (Souza-Júnior 2002). The human population density is approximately 0.6 inhabitants $/ \mathrm{km}^{2}$, and the local economy is based on subsistence agriculture, extensive cattle raising, and, more recently, $S$. nitens handicrafting (Seplan 2003a). This region has the largest legally protected continuous areas of Cerrado: the Jalapão State Park, with 158,000 ha; the Serra Geral do Tocantins National Park (Estação Ecológica), with 716,000, both created in 2001 (Silva and Bates 2002); and Nascentes do Parnaíba National Park, with 733,000 ha, created in 2002.

The Cerrado region is characterized by seasonal precipitation, with distinct rainy and dry seasons (Ratter et al. 1997). The mean precipitation in Jalapão region is $1,700 \mathrm{~mm}, 90 \%$ of which falls between October and April, and the annual mean temperature is $27^{\circ} \mathrm{C}$ (Seplan 2003b). The landscape is composed of scrubland areas on alfisoils where shrubs and trees (up to $10 \mathrm{~m}$ tall) occur among grasses (cerrado sensu stricto and campo sujo) (Ratter et al. 1997; Ribeiro and Walter 1998). The numerous watercourses are surrounded by gallery forests where the trees 

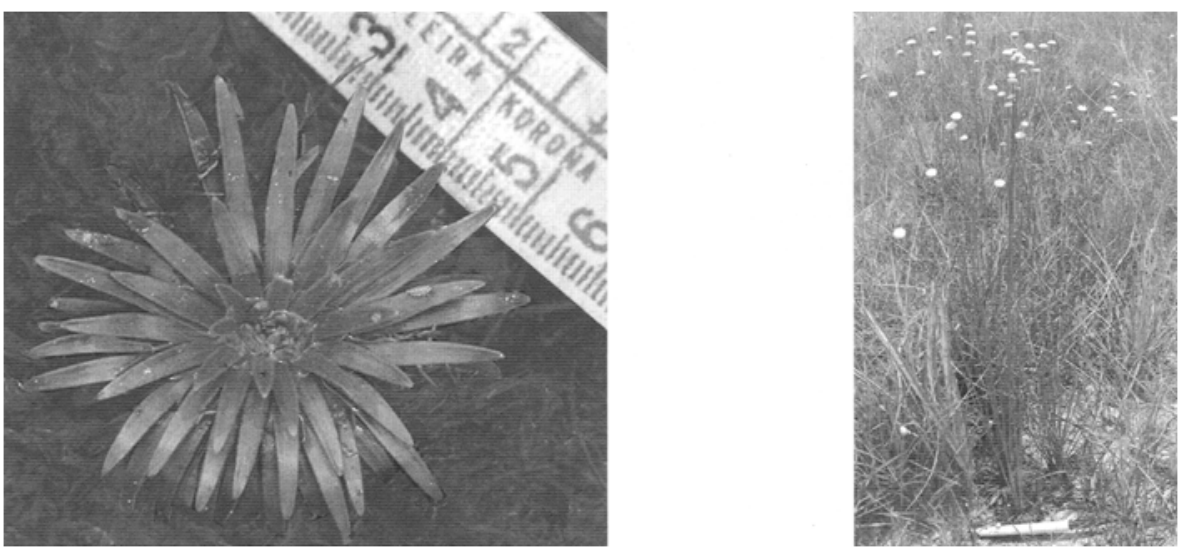

Fig. 2. A rosette (A) and three Syngonanthus nitens plants with scapes (B).

can reach up to $20 \mathrm{~m}$ height. In Jalapão, most of the gallery forests are swamp forests, (called veredas) dominated by buriti palm (Mauritia flexuosa L.f.). These swamp forests are delimited by humid grasslands (campos umidos) on organosoils dominated by grass species around $0.50 \mathrm{~m}$ in height and characterized by the occurrence of Xyridaceae, Cyperaceae, and Eriocaulaceae, including Syngonanthus nitens. These humid grasslands occur as a belt between the scrubland (cerrado or campo sujo) and the gallery forest (Ratter et al. 1997). In Jalapão, they are usually between 50 and $100 \mathrm{~m}$ wide.

\section{Species and Handicraft Activities}

Syngonanthus nitens is a perennial polycarpic herb with leaves arranged spirally in a basal rosette with diameter of ca. $4 \mathrm{~cm}$ (Fig. 2). The plants are clonal, and fertile rosettes can annually produce 1 to 10 scapes (flower stalks or stems), with each scape bearing a capitulum flower (Giulietti et al. 1996; Parra 1998; Schmidt 2005). In Jalapão, S. nitens' flowering starts in July, and seeds are produced from the beginning of September through October. Each capitulum bears on average $60 \pm 14$ seeds (minimum 0 and maximum 237; $\mathbf{n}=250$ ) measuring 0.7 to $1.0 \mathrm{~mm}$ length and 0.2 to $0.35 \mathrm{~mm}$ wide $(\mathrm{n}=100)$ and weighing about $0.033 \mathrm{mg}$ each (Schmidt 2005). Seed longevity in laboratory conditions, is around 10 months and germination rates (at $22 / 30^{\circ} \mathrm{C}$ ) can reach $92 \pm 7 \%$ (Schmidt et al. n.d.). Flowers and seeds are probably pollinated and dispersed by wind. The species occurs in all the Cerrado biome (Giulietti et al. 1996), in areas with intermediate humidity within the humid grasslands. In some regions of Bahia, Goiás, and Minas Gerais states, the scapes and flowerheads are harvested to be used as dried ornamental flowers (everlasting plants or semprevivas) (Giulietti et al. 1996). The use of scapes to make handicrafts takes place mainly in Jalapão region, but also in the cities of Tocantínia (Tocantins State) and São Domingos (Goiás State) on a smaller scale.

The handicrafts are made of coils of $S$. nitens scapes sewn tightly together with strips from Mauritia flexuosa young leaves. The handicrafts are bright and gold in color, hence their common name "golden grass" (capim dourado) (Fig. 1). The most traditional handicraft pieces are baskets and hats, but new products and designs have been introduced by tourists and by Sebrae, the governmental agency for working capacity building. Today, the artisans associations sell bracelets, belts, earrings, purses, and different kinds of boxes.

\section{ETHNOBotanical INTERVIEWS}

In December 2002, we conducted semistructured and nonstructured interviews with harvesters and artisans from six rural communities (Mumbuca, Carrapato, Formiga, Fazenda Nova, Rio Novo, and Prata) as well as in urban areas of Mateiros and Ponte Alta municipalities. We asked questions related to: the origin of handicraft activities in Jalapáo; the spread of the technique among the local communities; how artisans learn crafting; how, where and when the raw materials are obtained; how the humid grasslands are man- 
aged; the amount of time dedicated to handicraft activities; and the economic returns. In each locality, at least five interviews were conducted with men and women, depending on the opportunity and availability of harvesters and artisans. Additional information was also obtained later as the study progressed and local communities got to know and trust the research team. In total, we obtained information from more than 70 harvesters and artisans.

In August 2004, we recorded selling prices at local associations and interviewed four female artisans ( 15 to 64 years old) to estimate the time spent to make different pieces. We weighed these pieces (3-5 of each kind) to estimate the amount of scapes used and the per hectare profitability.

\section{Population Ecology and Effects of SCAPe Harvesting}

Harvesters from the Mumbuca community participated in the planning and execution of the ecological studies, which were initiated in August 2003 in three humid grasslands located in the Jalapão State Park ( $10^{\circ} 21^{\prime}$ S; $\left.46^{\circ} 36^{\prime} \mathrm{W}\right)$. To select our study sites, we chose humid grasslands that were traditionally considered good harvesting sites for the Mumbuca community, and that had been burned for the last time in 2002. The sites were separated from each other by 3 to $10 \mathrm{~km}$.

To characterize $S$. nitens density as well as rates of recruitment, mortality, resprouting, and flowering, in each study site we established $401 \times 1 \mathrm{~m}$ plots, where we counted all the $S$. nitens individuals and classified them as flowering or nonflowering. Then, in each plot, we established one $0.25 \times 0.25 \mathrm{~m}$ subplot where we tagged all the $S$. nitens individuals. Rosette diameter of the tagged plants was measured with a digital caliper; scape number and height from reproductive plants were recorded. We considered each rosette of leaves as an individual and noted whether it had evidence of resprouting. The individuals that apparently had originated from seeds and had not resprouted were called solitary genets. The individuals with resprout evidence (hereafter called ramets) may either be originated by resprout of another rosette and/or may be originated by seed, producing new rosettes themselves. Contact between rosettes and evidence of stem connections were the most important characteristics used to classify plants as ramets.

In addition, since there were relatively few flowering individuals within the $0.25 \times 0.25$ subplots, at each study we also tagged 200 flowering individuals outside the plots. Here no two ramets of a genet were tagged.

We tested the effects of harvest on $S$. nitens population ecology in two ways. We randomly selected half of the 40 plots and asked local harvesters to harvest them in the way they usually do. Therefore, not all individuals or scapes were harvested, and some rosettes were likely uprooted. We also removed all the scapes from 100 of the 200 flowering individuals outside of the plots, avoiding rosette uprooting. Both harvesting experiments were carried out from October 1518,2003 . Unharvested plots and plants were used as a control to be compared with harvested areas and plants

Censuses of all the plots and plants tagged were carried out five times over a one year period: in August 2003, October 2003, and February, June, and August 2004.

\section{STATistical Analyses Plants Inside the $1 \times 1$ Meter Plots}

We assessed differences in initial (August 2003) density of $S$. nitens plants among the three study sites using ANOVA, followed by the Tukey test. The initial densities of flowering plants were compared among sites using ANCOVA, with total density as the covariant. Within each site, we used t-tests to compare the initial total density and density of flowering individuals between control and harvested plots.

To compare densities of individuals in harvested versus control plots over the five census periods, we used the two-way repeated measures ANOVA. The treatment (control or harvested) and site were used as factors of the ANOVA. We used ANCOVA to compare flowering rates (in 2004) between harvested and control plots, using the total density per plot as the covariate. Data were square-root transformed to achieve normal distribution (Zar 1999).

\section{Plants Tagged outside the Plots}

We used the plants tagged outside the plots to verify the effects of harvest on individuals. Rates of survival, resprouting and flowering were compared between control and harvested plants using Chi-square tests. Rosette growth (diameter in $\mathrm{Au}$ gust 2004-diameter in August 2003) of harvested versus control plants was compared using t-tests. 
The number and height of scapes produced in 2004 (one year after experimental harvesting) were compared between control and harvested plants using ANCOVA, where the covariates were the number and height of scapes in the previous year.

\section{Comparison between Reproduction in Ramets Versus Solitary Genets}

We compared rates of survival of solitary genets versus ramets using a Chi-square test. For the survivorship analysis, we used only control individuals. For analysis of flowering rates, we considered all the individuals tagged in 2003 (i.e., before harvest), and then only plants from the control treatment in 2004. The ramets were randomly sampled so these comparisons could be made with samples of equal size.

\section{Results}

The Ethnobotany of

SYNGONANTHUS NITENS

The making of handicrafts of $S$. nitens began in Jalapão, in the Afro-Brazilian community of Mumbuca. Indigenous people, probably from the Xerente ethnic group, taught the art to local inhabitants when passing through the region around the 1930s. For decades the handicrafts were only made by women for household uses and/or sporadic selling. However, since the late 1990 s, the Tocantins State government has been advertising $S$. nitens handicrafts as a state trademark. During this period, the Jalapão region became a famous off-road and ecotourism destination. Together, these events caused a great increase in handicraft sales.

Due to interest in this alternative source of income, women - and more recently men and children-from all villages and cities in the region have started to harvest scapes and sew $S$. nitens handicrafts. Today, there are at least 12 local community associations with more than 600 artisans. The handicrafts are usually sold in small shops of local artisan associations. Some artisan associations have access to communication technology and are therefore able to receive orders and send them directly to shop owners in large Brazilian cities by mail. However, most of the sales are actually made by intermediaries who distribute the handicrafts widely and gain high profits. Presently, the local artisan associations are not able to compete with experienced intermediaries who come from large cities because they do have training in the necessary skills.

\section{Obtaining the Raw Materials for $S$. NITENS HANDICRAFTS}

The raw materials for $S$. nitens handicrafts are obtained from public lands, protected areas, and private lands. The private lands where $S$. nitens are harvested are areas where the landowners either live or else have hired people to oversee and take care of their property. Although harvesting inside protected areas is prohibited according to the Brazilian law, the government has still not purchased the land in Jalapão's designated protected areas from the prior landowners. Therefore, until the state government pays for the land, harvesters are not officially prohibited from harvesting in these protected areas.

The increase in demand for raw materials for S. nitens handicrafts has created an internal trade of $S$. nitens scapes and $M$. flexuosa strips. Consequently, some people, mainly men, have begun to collect raw materials exclusively to sell to artisans. Therefore they are "exclusively harvesters."

The strips (or buriti silk) used to sew the scapes of $S$. nitens are obtained from young unopened leaves of juvenile $M$. flexuosa palms throughout the whole year. Harvesters claim that this extraction does not injure the palms, especially if they allow the plant to produce one or two new leaves after harvest, before gathering a new leaf from the same plant. Harvested palms are easily identified because most of the leaf petiole is left in the plant. However, the increasing demand for strips can threaten palm individuals in areas close to the villages, which tend to be subject to higher harvesting pressures.

During the harvesting of $S$. nitens scapes, each harvester can obtain between $276 \mathrm{~g}-1,068 \mathrm{~g}$ (mean $666 \mathrm{~g} \pm 199 \mathrm{~g}$ ) of scapes in one hour. Usually, all the scapes from the plants that are harvested are taken. However, harvesters do nor generally collect all the scapes in any given area, thereby leaving around $20 \%$ of the plants unharvested. The scape harvesting is done between July and October. While knowledgeable artisans state that the harvesting should occur after midSeptember, new artisans, and particularly those who are exclusively-harvesters, maintain that the harvest can occur after mid-August or even earlier (Table 1). The early harvesting is carried out as a way to obtain more raw materials-that is, by collecting scapes before other harvesters get there. 
Table 1. Plant phenology events and harvesting activities of $S$. Nitens on Jalapão.

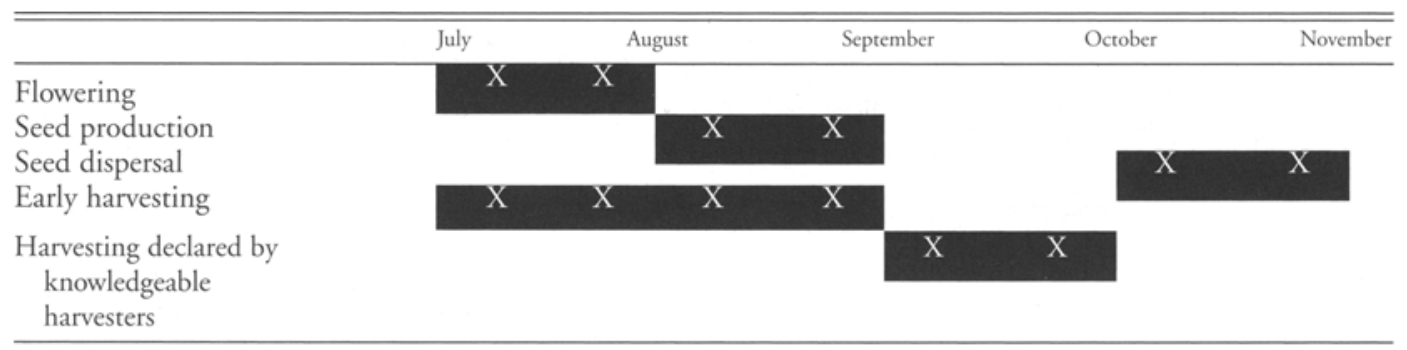

The early harvesting is favored by the existence of vast uninhabited areas that are difficult to access and control.

Today $S$. nitens harvesting is becoming more competitive, and harvesters stock scapes and sell them for higher prices after the harvest period. In September 2004, one kilogram of $S$. nitens scapes was sold for the equivalent of US\$7 to 10 , whereas the same amount could be sold for US $\$ 18$ in June of the following year (US\$1 is equivalent to about $\mathrm{R} \$ 2.3$ ).

All the local people interviewed asserted that scape production is higher one year after burning. According to this perception, the grasslands should be burned during the dry season (May to October) in order to stimulate scape production of $S$. nitens (i.e., flowering) in the following year. Therefore, harvesters maintain that the best management regime for $S$. nitens would involve the burning of humid grasslands every other year. However, in reality not all humid grassland areas are in fact burned so frequently, since the region is large and humid grasslands are common. Fire is also used to promote plant sprouting to feed the cattle during the dry season, a common practice in the Cerrado biome (Klink and Machado 2005; Mistry 1998). Fire frequency in the Jalapão region is high, and it is rare to find areas unburned for more than three years.

\section{Making of Handicrafts and ECONOMIC IMPORTANCE}

The time dedicated to making handicrafts is extremely variable among artisans. In general, women make handicrafts for a few hours every day while doing housework and raising children. Men make handicrafts when they have no outside activities, such as subsistence agriculture, cattle raising, or temporary jobs in farms or roads. Women's activities, therefore, tend to be more constant.
Artisans state that it is difficult to calculate accurately their monthly income because the time they dedicate to making handcrafts is highly variable and sales are not constant during the year. For example, during vacation periods, tourism is more intensive and so are the sales. Nonetheless, based on the time artisans dedicate to making their crafts and the average selling prices of different art pieces (Table 2), we estimate that the mean income generated from this activity ranges from US\$65 to 350 per artisan each month $(-\mathrm{R} \$ 150$ to $800 /$ month). Given that the scape density found in the ecological part of this study (about 50 scapes $/ \mathrm{m}^{2}$ ), and the amount of scapes needed to make each handicraft piece, we calculate that one hectare of humid grassland can yield between US $\$ 2,090$ and 6,670 each year. However, this calculation refers to only those areas of grassland where $S$. nitens occurs and not the whole grassland area.

\section{S. Nitens Population Ecology}

The density of $S$. nitens plants appears to be highly variable in humid grasslands (Fig. 3), since some of our plots had very high $S$. nitens densities (more than 220 individuals $/ \mathrm{m}^{2}$ ), while no $S$. nitens individuals were found in other plots. The initial densities of $S$. nitens differed among sites (ANOVA $\mathrm{F}_{2,117}=7.94, \mathrm{p}=0.001$ ). Site 1 had the lowest density of plants $(59 \pm 46$ individuals $/ \mathrm{m}^{2}$ [mean $\pm S D$ ], Tukey; $\mathrm{p}<0.03$ ), and sites 2 and 3 had a similar initial plant density $\left(94 \pm 51\right.$ and $91 \pm 42$ individuals $/ \mathrm{m}^{2}$, respectively, Tukey; $\mathrm{p}=0.98$, Fig. 3). The flowering rates of $S$. nitens also differed among sites in August 2003 (ANCOVA $F_{2,117}=27.45$, $\mathrm{p}<0.001$ ), with site 2 having the highest density of flowering plants $(56 \pm 17 \%)$, followed by site $1(47 \pm 17 \%)$, and then site $3(18 \pm 8 \%$, Tukey tests, $p<0.01$, Fig. 3). 


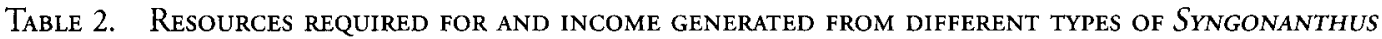
NITENS HANDICRAFTS. VARIATION IN THE ESTIMATED INCOME IS DUE TO THE VARIABLE TIME SPENT HANDICRAFTING AND ALSO TO THE KIND OF HANDICRAFT PIECE MADE.

\begin{tabular}{lccccc}
\hline \hline $\begin{array}{l}\text { Handicraft } \\
\text { Irem }\end{array}$ & $\begin{array}{c}\text { Mean } \\
\text { Weight }(\mathrm{g})\end{array}$ & $\begin{array}{c}\text { Number of Scapes } \\
\text { Requred }^{1}\end{array}$ & Price $^{2}$ (US\$) & $\begin{array}{c}\text { Time Spent } \\
\text { (Days) }^{3}\end{array}$ & $\begin{array}{c}\text { Estumated Yearly } \\
\text { Income }(\text { US\$) }\end{array}$ \\
\hline Purse & 206 & 1,805 & $15.0-21.5$ & $3-6$ & 2,100 \\
Hat & 185 & 1,619 & $19.3-23.6$ & $4-8$ & 1,115 \\
Sous plat & 57 & 503 & 4.3 & $0.5-1$ & 1,970 \\
$\begin{array}{l}\text { Small hat for } \\
\quad \text { keychains }\end{array}$ & 3 & 26 & 1.3 & $4-8$ & 2,415 \\
\begin{tabular}{l} 
Bracelet \\
\hline
\end{tabular} & 9 & 78 & 0.9 & $6-10$ & 2,145 \\
\hline
\end{tabular}

${ }^{1}$ Each scape weighs about $0.1143 \mathrm{~g}$, as estimated by weighing 100 scapes ( $\mathrm{n}=8 \times 100$ scapes).

${ }^{2}$ Minimum and maximum prices found in the association of Mumbuca community in August 2004.

${ }^{3}$ Estimated from interviews with four female artisans between 15 and 60 years old.

${ }^{4}$ Estimates assume 26 days of work/month. The Brazilian minimum salary in August 2004 was $\mathrm{R} \$ 260.00 /$ month. Estimates are based on the assumption that only one kind of item is made at a time. R $\$ 1.00 \approx$ US $\$ 0.43$ (June 2006).

Tagged plants produced an average of $2.3 \pm 1.9$ scapes; we rarely found individuals producing as many as 60 scapes. Scape production in the three sites varied between 28 and 106 scapes $/ \mathrm{m}^{2}$ in 2003 and 16 and 46 scapes $/ \mathrm{m}^{2}$ in 2004 . Among the individuals that flowered in 2004 in the control subplots, $49 \%$ flowered also in 2003 . Sixteen percent of the flowering individuals were new, recruited after August 2003.

About $60 \%$ (808 individuals) of the 1,336 individuals tagged in August 2003 were ramets. There were no significant differences in flowering rates between solitary genets and ramets in 2003 $\left(\chi^{2}=0.2 ; \mathrm{p}=0.64 ; \mathrm{n}=159\right)$ or in $2004\left(\chi^{2}=0.09\right.$; $\mathrm{p}=0.76 ; \mathrm{n}=60)$. Similarly, the number and height of scapes did not differ significantly between solitary genets and ramets in 2003 ( $t$ tests; $p>0.2 \mathrm{df}=652$.). However, in 2004 , ramets produced more $(\mathrm{t}=-2.6 ; \mathrm{p}=0.012 ; \mathrm{df}=92)$ and taller $(\mathrm{t}=-2.4 ; \mathrm{p}=0.017 ; \mathrm{df}=92)$ scapes than $\mathrm{did}$ the solitary genets.

\section{Effects of $S$. nitens Scape Harvesting}

There were no significant differences in $S$. nitens density between experimentally harvested $1 \times 1 \mathrm{~m}$ plots and control plots $\left(\mathrm{F}_{1,114}=0.05\right.$, $\mathrm{p}=0.824)$, and there were no significant interactions between harvest and site $\left(\mathrm{F}_{2,1}=0.8\right.$; $\mathrm{p}=0.45$, Fig. 3). In addition, harvesting did not significantly affect flowering rates in the year following harvest (2004) in any of the studied sites (ANCOVAS, $\mathrm{p}>0.28 \mathrm{df}=1 ; 1 ; 37$ ) (Fig. 3). It is important to note that in August 2003 (before harvest) there were no significant differences in $S$. nitens density between plots assigned to be har- vested and used as control plots in any of the three sites ( $t$ tests; $\mathrm{p}>0.2, \mathrm{df}=19$ ).

For the plants tagged outside the plots, there were significant differences between control and harvested plants in rates of flowering, scape production, vegetative reproduction, and rosette growth. However, these harvests effects did not show any consistent pattern among the sites (Table 3).

\section{Discussion}

\section{ECONOMIC IMPORTANCE OF $S$. NITENS}

The successful trade of NTFP, which allows for biodiversity conservation and contributes to the livelihoods of local communities, is a complex challenge that depends on numerous economical and ecological variables (Belcher et al. 2005; Hall and Bawa 1993). The trade of handicrafts of Syngonanthus nitens is an important economic option for families in Jalapão for several reasons. These include the fact that $S$. nitens handicrafts are well priced in the region and in Brazilian and foreign urban areas. Our results indicate that at present $S$. nitens allows Jalapão artisans to earn about 1.5 times the minimum Brazilian salary (US\$110/ month in August 2004) or even more. This is highly relevant in a region where the majority of the people do not have formal jobs, and rarely have incomes higher than twice the minimum salary. These earnings are high in comparison to other NTFP from the Cerrado region (Sawyer et al. 1999) and other parts of the world (Ghimire et al. 2005; Gunatilake et al. 1993; Marshall and Newton 2003; Reis et al. 2000; Runk 1998; Ticktin et al. 2003). The per-hectare profitability, 

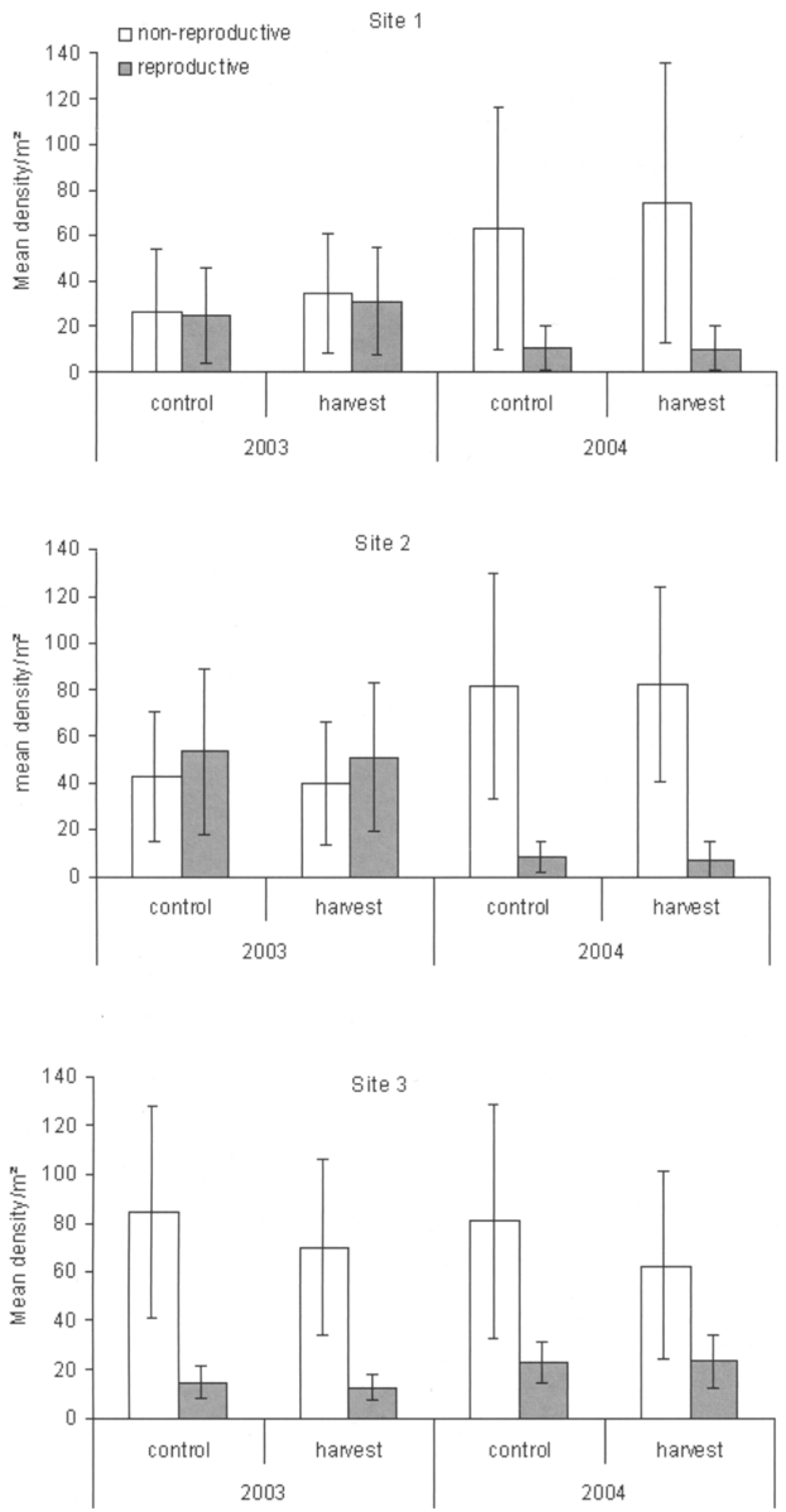

Fig. 3. Density (mean \pm SD) of S. nitens individuals in August 2003 and August 2004, in three humid grasslands sites $(\mathrm{n}=20$ control plots and $\mathrm{n}=20$ harvest plots in each site). The scapes were harvested in October 2003 . 
Table 3. Survival, growth and Reproduction of harvested Versus CONTROL SYNGonanthus nitens PLANTS. ALL PLANTS HAD SCAPES THAT WERE HARVESTED IN OCTOBER 2003. ${ }^{1}$

\begin{tabular}{lcccccc}
\hline & \multicolumn{2}{c}{ Site 1 } & \multicolumn{2}{c}{ Stre 2 } & \multicolumn{2}{c}{ Site 3 } \\
\hline & Control & Harvest & Control & Harvest & Control & Harvest \\
\hline Number of plants & 99 & 99 & 92 & 93 & 98 & 96 \\
Survival (\%) & 99.0 & 97.0 & 98.9 & 98.9 & 100.0 & 96.9 \\
New resprouts (\%) & 70.7 & 67.8 & 58.3 & 65.1 & $36.1^{\text {a }}$ & $50.0^{\alpha}$ \\
Rosette growth (mm)* & $2.1 \pm 12.9$ & $2.9 \pm 10.2$ & $-0.4 \pm 14.2^{*}$ & $-6.5 \pm 16.1^{*}$ & $-1.4 \pm 5.7^{*}$ & $0.7 \pm 7.4^{*}$ \\
Flowering plants (\%) & $29.6^{\dagger}$ & $40.8^{\dagger}$ & $22.8^{\dagger}$ & $14.0^{\dagger}$ & $4.0^{\dagger}$ & $25.8^{\dagger}$ \\
Number of scapes & $2.2 \pm 1.1^{\ddagger}$ & $5.0 \pm 4.3^{\ddagger}$ & $2.2 \pm 1.8$ & $2.1 \pm 1.8$ & $1.3 \pm 0.5$ & $1.8 \pm 0.9$ \\
Scape height (cm) & $48.3 \pm 10.1$ & $46.0 \pm 9.0$ & $43.6 \pm 8.3$ & $47.1 \pm 4.8$ & $31.9 \pm 2.8$ & $32.8 \pm 9.8$ \\
\hline
\end{tabular}

Based on harvest experiments with plants tagged outside plots in August 2003.

- Differences in total number of plants is due to the fact that some plants and their tags were not found in subsequent samples, probably because of the increase of grass cover during the one-year period;

* Mean \pm SD; differences in rosette diameter variation (final--mitial diameter), between control and harvested plants, $t$-test, $\mathrm{p}<0.03$;

${ }^{+}$Differences in frequency between control and harvested plants, $\left(\chi^{2} ; p<0.04\right)$;

${ }^{\ddagger}$ Mean \pm SD; differences in scape production between control and harvested plants (ANCOVA) considering the 2003 values as covariables, $p=0.01$.

US\$2,090 to 6,670/year, is also high for NTFP (Belcher et al. 2005; Murthy et al. 2005; Ticktin et al. 2003). In addition, this income can be enhanced if the social and environmental benefits of the products could be considered (Anderson and Putz 2002). This can be attained by increasing the organizational and bargaining capacity of the local associations (Belcher et al. 2005) while incorporating management techniques that are ecologically sustainable.

Three additional aspects of $S$. nitens handicrafting make this activity locally important. First, economic activities in this region are typically carried out by men, such as physical labor on farms, house building, and road construction. In contrast, the handicrafts provide income mostly for women who generally do not have other income sources. Second, handicraft production allows artisans to dedicate time to other activities, such as housework, subsistence agriculture, and cattle raising, and does not require seasonal migration, as do some available jobs in the region. Finally, scapes can be stored to be used year around and handicrafts can be sold whenever there are buyers interested in them, since they are not perishable, which is a common problem among a number of NTFP (Godoy and Bawa 1993).

\section{Population Ecology of $S$. Nitens}

Syngonanthus nitens populations rely considerably on sexual reproduction, a characteristic recorded for other monocotyledonous clonal species (e.g., Guardia et al. 2000). The fact that approximately $40 \%$ of new recruits come from seeds is consistent with the high rates of seed production and germination (Schmidt et al. n.d.). Ramets and solitary plants have similar flowering rates; therefore, both can generate new seedlings.

Observations from two of the study sites coincide with the traditional knowledge that $S$. nitens flowering rates are greater one year after burning. However, these observations should be taken with caution because of the spatial and temporal variability in $S$. nitens population ecology, and also because environmental factors other than fire (e.g., amount of biomass and soil cover in the grasslands) may influence $S$. nitens flowering. Indeed, site 3 had a higher flowering rate in 2004, two years after burning, than in 2003. Longerterm experimental studies will be necessary to understand the importance of fire on the population ecology of this species.

\section{EFFECTS OF HARVEST ON S. NITENS POPUlations}

High spatial and temporal variability are common in the dynamics of plant populations and can make the effects of harvesting difficult to assess (Boot and Gullison 1995; Hall and Bawa 1993). We did not identify consistent effects of scape harvesting on any of the population parameters analyzed over the one year study period. Syngonanthus nitens population dynamics may be 
more influenced by factors such as soil humidity, nutrient availability, soil vegetation cover, and fire than by scape harvesting per se. More research will be necessary to assess this.

It is possible that harvesting $S$. nitens scapes in mid-October does not influence the individual survival, growth, or reproductive capacity (sexual and asexual) of this species at all. Several ecologi$\mathrm{cal}$ and harvesting characteristics of $S$. nitens support this hypothesis. First, scape harvesting does not cause death of harvested individuals, except by occasional rosette uprooting; second, the rates of flowering and vegetative propagation of harvested individuals did not change in the year after harvesting; and third, scapes are not essential tissues for plant survival and growth.

\section{IMPLICATIONS FOR SUSTAINABLE HARVESTING OF $S$. NITENS}

Some aspects of both the harvesting and handicraft activities of $S$. nitens appear to contribute to its sustainability. Syngonanthus nitens is abundant in Jalapão and exhibits high rates of survival and recruitment both from seeds and vegetative propagation, which can prevent high population fluctuations (Cook 1979). Since the species is polycarpic, the same individual can produce scapes several times in its lifetime. Moreover, plant maturation is fast, and scape production can occur during the first year of the individual's life. This fast production contrasts with NTFP extracted from species with long life cycles (Peres et al. 2003) and with palm and herb species with intermediate life cycles (Reis et al. 2000; Siebert 2004; Ticktin and Johns 2002).

Given that about $40 \%$ of S. nitens recruits come from seeds, one potential effect of scape harvesting could be a decrease in seed availability, especially if the harvesting occurs before seed maturation and dispersal. This could reduce seedling recruitment and cause population size reduction. Harvesters and some preliminary tests indicate that early harvesting, before September, can cause more rosette uprooting, killing adult plants with sexual and clonal reproductive potential. The timing of harvesting is likely extremely important to the potential for sustainability of $S$. nitens handicrafts. We only tested the impacts of harvesting in October, which may be significantly different from the impacts of harvesting in earlier months when the plants are still flowering or with immature seeds. Harvesting after seed maturation (after mid-September) allows the dispersal of at least part of the seeds before or during scape harvesting.

Reductions in population size of other Eriocaulaceae species, including other Syngonanthus spp. whose flowerheads are exploited as dry ornamental plants (sempre-vivas) in Central Brazil, have been attributed to scape harvesting during the flowering period (L.C. Bede, personal communication; Giulietti et al. 1996). In this context, a central aspect of the potential sustainability of $S$. nitens for handicrafts relates to the fact that scapes, and not flowerheads, are used. When Eriocaulaceae species are used for ornamental purposes, the economic value is determined by the color and structure of the flowerheads, and these characteristics change, decreasing quality and value, after seed production (L.C. Bede, personal communication). In contrast, harvesting of $S$. nitens scapes after seed production has no negative impact on the handicraft activity. In addition, the flowerhead can be cut and the seeds dispersed in the grasslands during the harvesting, also with no harm to the handicraft activity. Therefore, the recommendation for later harvesting is feasible for the scape handicrafts, but not for flowerhead ornamental exploitation.

Based on the above results, the Tocantins State Government, through its Environmental Agency (Naturatins), established a regional law (Portaria $55 / 2004$ and $092 / 2005$ ) allowing scape harvesting only after September $20^{\mathrm{th}}$, and requiring flowerhead cutting and dispersal in the grassland areas just after scape harvesting. This regional law can be updated regularly whenever new information is obtained, and therefore can be an efficient tool for contributing to the sustainability of $S$. nitens handicraft activities.

In this case, we see a real possibility for achieving conservation of natural ecosystems combined with income generation to local communities. To guarantee this, land use changes (such as conversion to agricultural areas or cattle pastures) will need to be prevented in the humid grasslands in Jalapão, and harvest activities should be organized, with early extraction avoided. In addition, local associations need to improve their organizational and marketing effectiveness so that they are collectively able to control harvesting activities and use the adoption of sustainable management techniques as a way to provide added value to their products. Another important aspect needed to ensure sustainability in both ecological and economic terms is the maintenance of harvesters' 
access to the harvesting areas. This is especially important since the high value of the raw material for $S$. nitens handicrafts is already encouraging local landowners to restrict the access to their land and/or charge harvesters for extracting NTFP. One possible way to help ensure harvesters' access would be through the implementation of Extractives Reserves, which have been established elsewhere in Brazil (Allegretri 1990) and could also help legitimize local control of harvesting activities.

Finally, in order to develop an effective management plan for $S$. nitens and the humid grasslands in which it is found, it will also be essential to (1) study the effects of fire on $S$. nitens population dynamics and humid grasslands diversity, and (2) to determine the effects of the exploitation of the young leaves of buriti palm.

\section{Acknowledgments}

We thank the Mumbuca Community for receiving the research team and becoming part of it, the landowners that allowed the experiments in their lands, and the Jalapão State Park and Estação Ecológica Serra Geral do Tocantins for support during field work and planning activities. We especially thank Daniel E. Moerman, two reviewers, and the associated editor for their very relevant suggestions on the manuscript. We also thank T. Ticktin, K. Holl, R. Girling, A. Sampaio, M. Sampaio, D. Vieira, I. Belloni, and the Ecology and Conservation Laboratory research group from Embrapa, Brasília, for important suggestion during all parts of the work and manuscript preparation. Financial support was given by Diretoria de Florestas-Ibama and WWFBrazil.

\section{Literature Cited}

Aguiar, L. M. S., R. B. Machado, and J. MarinhoFilho. 2004. A diversidade biológica do Cerrado. Pages $17-40$ in L. M. S. Aguiar and A. J. A. Camargo, eds. Cerrado ecologia e caracterizaçāo. Embrapa, Planaltina-DF.

Allegretti, M. H. 1990. Extractive reserves: An alternative for reconciling development and environmental conservation in Amazonia. In A. B. Anderson, ed.. Alternatives to deforestation: Steps toward sustainable use of the Amazon Rain Forest. Columbia University Press, New York.

Anderson, P. J., and F. E. Putz. 2002. Harvesting and conservation: Are both possible for the palm Iriartea deltoidea? Forest Ecology and Management 170:271-283.
Belcher, B., M. Ruíz-Pérez, and R. Achdiawan. 2005. Global patterns and trends in the use and management of commercial NTFPs: Implications for livelihoods and conservation. World Development 33:1435-1452.

Boot, R. G. A., and R. E. Gullison. 1995. Approaches to developing sustainable extraction systems for tropical forest products. Ecological Applications 5:896-903.

Cook, R. E. 1979. Asexual reproduction: A further consideration. American Naturalist 113:769-772.

Endress, B. A., D. L. Gorchov, M. B. Peterson, and E. P. Serrano. 2004. Harvest of the palm Chamaedorea radicalis, its effects on leaf production, and implications for sustainable management. Conservation Biology 18:822-830.

Furley, P. 2004. Tropical savannas. Progress in Physical Geography 28:581-591.

Ghimire, S. K., D. McKey, and Y. AumeeruddyThomas. 2005. Conservation of Himalayan medicinal plants: Harvesting patterns and ecology of two threatened species, Nardostachys grandiflora DC. and Neopicrorhiza scrophulariiflora (Pennell) Hong. Biological Conservation 124:463-475.

Giulietti, A. M., M. G. L. Wanderley, H. M. LonghiWagner, J. R. Pirani, and L. R. Parra. 1996. Estudos em "sempre vivas": Taxonomia com ênfase nas espécies de Minas Gerais, Brasil. Acta Botanica Brasilica 10:329-383.

Giulietti, N., A. M. Giulietti, J. R. Pirani, and N. L. Menezes. 1988. Estudos em semprevivas: Importância econômica do extrativismo em Minas Gerais. Acta Botanica Brasilica 1(2):179-193.

Godoy, R. A., and K. Bawa. 1993. The economic value and sustainable harvest of plants and animals from the tropical forest: Assumptions, hypotheses and methods. Economic Botany 47:215-219.

Guardia, R., J. Raventos, and H. Caswell. 2000. Spatial growth and population dynamics of a perennial tussock grass (Achnatherum caldmagrostis) in a badland area. Journal of Ecology 88:950-963.

Gunatilake, H. M., D. M. A. H. Senaratne, and P. Abeygunawardena. 1993. Role of non-timber forest products in the economy of peripheral communities of Knuckles National Wilderness Area of Sri Lanka: A farming system approach. Economic Botany 47:275-281.

Hall, P., and K. Bawa. 1993. Methods to asses the impact of extraction of non-timber tropical forest products on plant populations. Economic Botany 47:234-247.

Klink, C. A., and R. B. Machado. 2005. Conservation of the Brazilian Cerrado. Conservation Biology 19:707-713.

Marris, E. 2005. Conservation in Brazil: The forgotten ecosystem. Nature 437:944-946.

Marshall, E., and A. C. Newton. 2003. Non-timber forest products in the community of El Terrero, Sierra 
de Manantlán Biosphere Reserve, Mexico: Is their use sustainable? Economic Botany 57:262-278.

Martin, G. 2004. Ethnobotany-A methods manual. Earthscan, London.

Mendonça, M. P., and L. V. Lins. 2000. Livro Vermelho das espécies ameaçadas de extinção da flora de Minas Gerais. Fundação Biodiversitas, Fundação Zôo Botânica de Belo Horizonte.

Mistry, J. 1998. Fire in the cerrado (savannas) of Brazil: An ecological review. Progress in Physical Geography 22:425-448.

Mittermeier, R. A., N. Myers, and C. G. Mittermeier 2000. Hotspots: Earth's biologically richest and most endangered terrestrial ecoregions. CEMEX, Mexico City.

Murthy, K., P. R. Bhat, N. H. Ravindranath, and R. Sukumar. 2005. Financial valuation of non-timber forest product flows in Uttara Kannada district, Western Ghats, Karnataka. Current Science 88:1573-1579.

Myers, N., R. A. Mittermeier, C. G. Mittermeier, G. A. B. d. Fonseca, and J. Kent. 2000. Biodiversity hotspots for conservation priorities. Nature 403:853-858.

Nepstad, D., and S. Schwartzman. 1992. Non-timber products from tropical forests: Evaluation of a conservation and development strategy. Advances in Economic Botany 9, The New York Botanical Garden Press, N.Y.

Oliveira, P. S., and R. J. Marquis, eds. 2002. The Cerrados of Brazil. Columbia University Press, New York.

Paoli, G. D., D. R. Peart, M. Leighton, and I. Samsoedi. 2001. An ecological and economic assessment of the non-timber forest product Gaharu Wood in Gunung Palung National Park, West Kalimantan, Indonesia. Conservation Biology 15:1721-1732.

Parra, L. R. 1998. Flora da Serra do Cipó, Minas Gerais: Syngonanthus Rhuland (Eriocalaceae). Boletim de Botânica da Universidade de São Paulo 17:219-254.

Peres, C. A., C. Baider, P. A. Zuidema, L. H. O. Wadt, K. A. Kainer, D. A. P. Gomes-Silva, R. P. Salomáo, L. L. Simóes, E. R. N. Franciosi, F. C. Valverde, R. Gribel, G. H. Shepard, Jr., M. Kanashiro, P. Coventry, D. W. Yu, A. R. Watkinson, and R. P. Freckleton. 2003. Demographic threats to the sustainability of Brazil nut exploitation. Science 302:2112-2114.

Ratter, J. A., J. F. Ribeiro, and S. Bridgewater. 1997. The Brazilian cerrado vegetation and threats to its biodiversity. Annals of Botany 80:223-230.

Redford, K. H., and C. Padoch, eds. 1992. Conservation of neotropical forests. Columbia University Press, New York.
Reis, M. S., A. C. Fantini, R. O. Nodari, A. Reis, M. P. Guerra, and A. Mantovani. 2000. Management and conservation of natural populations in Atlantic rain forest: The case study of palm heart (Euterpe edulis Martius). Biotropica 32:894-902.

Ribeiro, J. F., and B. M. t. Walter. 1998. Fitofisionomias do bioma Cerrado. Pages 89-152 in S. M. Sano and S. P. d. Almeida, eds. Cerrado ambiente e flora. Embrapa, Planaltina-DF.

Runk, J. V. 1998. Productivity and sustainability of a vegetable ivory palm (Phytelephas aequatorialis, Arecaceae) under three management regimes in northwestern Ecuador. Economic Botany 52:168182.

Sawyer, D., F. Scardua, and L. Pinheiro. 1999. Extrativismo vegetal no Cerrado: Análise de dados de produçāo 1980-1993. ISPN, Brasília.

Schmidt, I. B. 2005. Etnobotânica e ecologia populacional de Syngonanthus nitens: "Sempre-viva" utilizada para artesanato no Jalapão, TO. M.Sc. Thesis in Ecology. University of Brasília, Brasília.

- I. B. Figueiredo, F. Borghetti, and A. O. Scariot. n.d.. Produção e germinação de sementes de "capim dourado," Syngonanthus nitens (Bong.) Ruhland (Eriocaulaceae): implicaçōes para o manejo. Acta Botanica Brasilica (submitted).

Seplan. 2003a. Plano de Manejo do Parque Estadual do Jalapão, Palmas, TO.

. 2003b. Zoneamento Ecológico Econômico de Tocantins, www.seplan.to.gov.br.

Siebert, S. E. 2004. Demographic effects of collecting rattan cane and their implications for sustainable harvesting. Conservation Biology 18:424-431.

Silva, J. M. C. d., and J. M. Bates. 2002. Biogeographic patterns and conservation in the South American Cerrado: A tropical savanna hotspot. BioScience 52:225-234.

Souza-Júnır, W. C. 2002. Análise de viabilidade sócio-econômico-ambiental da transposição de águas da Bacia do rio Tocantins para o rio São Francisco na região do Jalapão/TO. Conservation International do Brasil, Brasília-DF.

Ticktin, T. 2004. The ecological implications of harvesting non-timber forest products. Journal of Applied Ecology 41:11-21.

— and T. Johns. 2002. Chinanteco management of Aechmea magdalenae: Implications for the use of TEK and TRM in management plans. Economic Botany 56:177-191.

- T. Johns, and V. C. Xoca. 2003. Patterns of growth in Achmea magdalenae (Bromeliaceae) and it potential as a forest crop and conservation strategy. Agriculture, Ecosystems and Enviroment 94:123-139.

Zar, J. H. 1999. Biostatistical analysis. Prentice Hall, New Jersey. 